\title{
Kegunaan Televisi Dalam Membantu Memecahkan Masalah Belajar dan Pembelajaran
}

\author{
Mubiar Agustin \\ Dosen pada Program Studi Pendidikan Guru Pendidikan Anak Usia Dini \\ Email:mubiar@upi.edu \\ Dewi Sri Mulyani \\ Pascasarjana Teknologi Pendidikan IPI Garut \\ Email: dewibachtiar48@gmail.com \\ Yuni Fatimatizzahro \\ Pascasarjana Teknologi Pendidikan IPI Garut \\ Email: yunifzahroo@gmail.com
}

\begin{abstract}
Abstrak
Kemajuan teknologi yang cepat dan pesat, berdampak juga pada bidang pendidikan, yang menghasruskan menerapkan TIK dalam kegiatan pembelajaran.Pada Negara Thailand, Afrika Selatan dan Slovenia memiliki kelebihan dan kekurangan.salah satu kekurangannya yaitu ketidak merataan fasilitas untuk penggunaan TIK, keahlian guru yang kurang maksimal, atau lokasi daerah yang sulit dijangkau yang dapat membuat suatu ketertinggalan. ". Data ini berasal dari kuesioner konteks nasional (NCQ) (dijawab oleh koordinator penelitian nasional SITES [NRC] untuk setiap negara atau sistem pendidikan).Kuesioner yang diberikan secara online oleh Pusat Pengelolaan Data IEA pada kuartal terakhir di tahun 2016.Salah satu solusi yang dapat digunakan dalam mengatasi permasalahan tersebut yaitu dengan menerapkan TV Edu.yang di dalamnya berisikan mengenai pembahsan sautu bahanajar dan suatu permasalahan pelajaran yang di kumpulkan berdasarkan pengajuan melalui telepon, email dan jugasosial media. Pelaksanaan TV Edu di sesuaikan dengan kebijakan serta kurikulum masing-masing Negara, dan program ini berpacu pada model pembelajaran Learning Start With a Question yang dimana satu pembelajaran dimualai dengan pertayaan.Kata Kunci :TIK, Pedagogi, TV Edu.
\end{abstract}

\begin{abstract}
Rapid technological advances and rapid, also impacted on the field of education, which makes it difficult to apply ICT in learning activities. In Thailand, South Africa and Slovenia countries have advantages and disadvantages. , or the location of hard-to-reach areas that can create a lag. ". This data comes from the national context questionnaire (NCQ) (answered by the national research coordinator SITES [NRC] for each country or education system). Questionnaire provided online by the IEA Data Management Center in the last quarter of 2016. One of the solutions that can used in overcoming these problems by implementing TV Edu. which contains the discussion of learning materials and a problem of lessons gathered based on telephone, email and social media submissions. The implementation of Edu TV is adjusted to the policies and curriculum of each country, and this program is driven by the Learning Start with a Question learning model in which one learning begins with questions.
\end{abstract}

Keywords: ICT, Pedagogy, TV E 


\section{PENDAHULUAN}

Perkembangan dan kemajuan ilmu dan teknologi di era sekarang ini semakin pesat dan cepat.Kemajuan dan perkembangan itu pun tidak hanya mencakup dalam satu bidang saja, melainkan mencakup segala hal. Salah satu kemajuan dan perkembangan ilmu dan teknologi yang dapat kita rasakan adalah dalam bidang pendidikan, dimana pada zaman dahulu suatu pendidikan itu tidak tercampuri oleh teknologi. Tetapi sekarang teknologi merupakan bagian dari suatu satuan pendidikan.

Kemajuan teknologi yang cepat dan perubahan yang besar, berdampak langsung pada kegiatan sehari-hari dan pada pola pikir manusia. Sama hal-nya dengan kemajuan teknologi dalam bidang pendidikan, yang pada dasarnya diciptakan untuk membantu dan menunjang sesuatu kegiatan pembelajaran yang mengakibatkan bayak perubahan. Perubahan tersebut telah mendorong banyak diskusi tentang peran dan proses pendidikan serta peran teknologi informasi dan komunikasi (ICT) dalam pengajaran dan pembelajaran di era baru.

Teknologi merupakan sebuah sarana yang dapat digunakan untuk memecahkan sebuah masalah, dan dengan adanya teknologi dalam bidang pendidikan diharapkan juga dapat memecahkan suatu masalah seperti dalam kegiatan pembelajaran yang nantinya teknologi tersebut dapat digunakan sebagai media pembelajaran. Maka dari itu, dengan adanya suatu perubahan besar baik dari segi pola pikir

yang dapat membuat suatu ketertinggalan. Salah satu solusi yang dapat digunakan dalam mengatasi permasalahan kekurangan tersebut yaitu maupun kebutuhan sehingga terciptanya "Teknologi Pembelajran".

Terciptanya suatu perkembangan serta kemajuan tekonologi dalam pendidikan, tidak luput dari suatu masalah ketidak merataan pada suatu daerah tertentu yang secara tidak langsung membuat ketertinggalan dan kurang maksimalnya penggunakaan TIK dalam kegiatan pembelajaran. Ketidak merataanya tersebut bisa diakbiatkan oleh lokasi serta jangkauan dari daerah tersebut, fasilitas, serta keahlian guru yang dirasa belum cukup untuk megaplikasikan TIK dalam kegiatan pembelajaran.

Dengan adanya beberapa masalah mengenai penggunaan dan penerapan TIK dalam pembelajaran, telah dilakukannya suatu penelitian di beberapa bagian negara di dunia yang telah ditulis dalam buku berjudul "PEDAGOGY AND ICT USE IN SCHOOLS AROUND THE WORLD : Finding From the IEA Sites 2006 Study". Salah satu negara yang dilakukanya penelitian adalah Thailand, Afirka Selatan, dan Slovenia.

\section{KAJIAN LITERATUR}

Kemajuan teknologi yang cepat dan pesat, berdampak juga pada bidang pendidikan, yang mengharuskan menerapkan TIK dalam kegiatan pembelajaran. Pada negara Thailand, Afrika Selatan dan Slovenia memiliki kelebihan dan kekurangan. Salah satu kekurangannya yaitu ketidak merataan fasilitas untuk penggunaan TIK, keahlian guru yang kurang maksimal, atau lokasi daerah yang sulit dijangkau dengan menerapkan TV Edu.yang di dalamnya berisikan mengenai pembahsan suatu bahan ajar dan suatu 
permasalahan pelajaran yang dikumpulkan berdasarkan pengajuan

melalui telepon, email dan juga sosial media.

Menurut Darmawan (2017), bahwa keberadaan televise dapat menjadi sumber belajar bagi para guru di sekolah, mengingat dalam siaran televisi, banyak mengandung informasi yang komprehensif sehingga guru dapat memperoleh learning resources yang cukup untuk bekal mendidik para siswanya. Dari pendapat tersebut sangat jelas bahwa peran dari ICT dalam penyelenggaraan pendidikan dan pembelajaran dapat berfungsi ganda, yaitu: (a) menenamkan kebiasaan menggunaan teknologi untuk pendidikan; (b) menantang peran dan inovasi penggunan sesuai dengan bidangnya masing-masing. Sebagaimana dalam kajian pada Paperini, dimana aspek pedagogy televisi di berbagai negara selama ini telah menjadi solusi dalam penyelenggaraan pembelajaran bagi warga negaranya.

\section{METODOLOGI}

Sesuai yang tercantum dalam buku berjudul "PEDAGOGY AND ICT USE IN SCHOOLS AROUND THE WORLD : Finding From the IEA Sites 2006 Study". Data utamanya ini berasal dari kuesioner konteks nasional (NCQ) (dijawab oleh koordinator penelitian nasional SITES [NRC] untuk setiap negara atau sistem pendidikan). Namun, juga menggunakan beberapa indikator demografi dan teknologi dari Laporan Pembangunan Manusia 2006 (United Nations Development Programme, 2006). Keempat bidang kontekstual yang terdapat pada bab ini sebagai atribut sistem pendidikan. Pedagogi dan TIK dalam pembelajaran adalah proses yang terjadi terutama di tingkat kelas dan sekolah, tetapi tren umum atau pola yang muncul dalam kaitannya dengan proses ini dapat dianggap karakteristik dari keseluruhan sistem pendidikan. Pernyataan ini sejajar dengan perspektif yang diberikan dalam Plomp, Anderson, Law, dan Quale (2003).

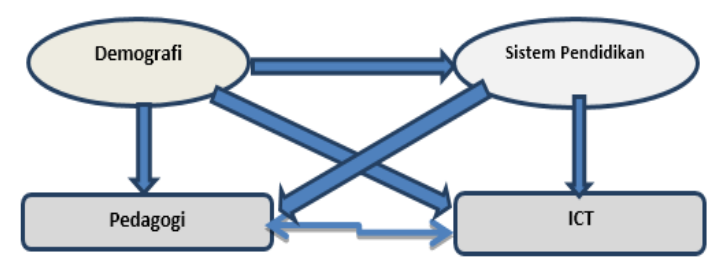

Gambar.1 Empat bidang faktor kontekstual

Pertanyaan penelitian yang berkaitan dengan empat bidang

a. Demografi

Indikator budaya demografis dan pendidikan di seluruh sistem diperoleh dari UNDP Human Development Report 2006 yang diterdiri dari populasi , urbanisasi, pendapatan, ketimpangan pendapatan, tingkat pendidikan, dan investasi dalam pendidikan. Tujuannya adalah untuk mengeksplorasi sejauh mana indikator ini memprediksi struktur dan pedagogi yang terkait dengan pendidikan TIK. Pertanyaan penelitian yang kami ajukan berkaitan dengan bidang berikut: Di antara sistem pendidikan yang dipelajari, apa distribusi indikator (dan bagaimana mereka berbeda) dalam hal populasi, PDB, ketidaksetaraan pendapatan, selama 
pengguna telepon per 1.000 penduduk, dan pengguna internet per 1.000 penduduk?

b. Struktur sistem pendidikan

pendanaan dan komponen kurikuler; (iii) persyaratan pengembangan profesional untuk guru; dan (iv) komponen kurikulum matematika dan sains. Data studi kasus Kozma (2003) mendukung pentingnya kekuatankekuatan ini. Dalam mengeksplorasi peran faktor-faktor ini, dipandu dari pertanyaan penelitian yang lebih luas, yaitu: Apa pola distribusi di seluruh sistem pendidikan dalam hal tingkat pendidikan umum, investasi dalam pendidikan, pengembangan profesional guru, sentralisasi kurikulum dan pendanaan, dan kurikulum matematika dan komponen kurikulum sains?

c. Pedagogi

Instrumen NCQ berisi sejumlah pertanyaan yang berkaitan dengan tren dalam praktik pedagogis dalam setiap sistem pendidikan secara keseluruhan.

Beberapa ini difokuskan pada reformasi instruksional atau perubahan. Indikator persiapan guru juga termasuk dalam pedagogi. Untuk pertanyaanpertanyaan ini atau indikator, kami terutama tertarik pada distribusi indikator pedagogis lintas sistem pendidikan. pedagogi adalah ilmu atau seni dalam menjadi seorang guru. Istilah ini merujuk pada strategi pembelajaran atau gaya pembelajaran.

d. Kebijakan dan kegiatan terkait TIK Seperti halnya bidang pedagogi, ICT adalah dimensi utama yang menarik, terutama dalam hal interaksinya
Pada hal ini diidentifikasi empat set indikator untuk lingkup ini: (i) sistem pendidikan investasi dan output; (ii) sentralisasi dalam hal sumber

dengan pedagogi. Maka memutuskan untuk menjelajah pertanyaan umum berikut: Sejauh mana sistem pendidikan mengimplementasikan ICT dan juga menggabungkannya dengan reformasi pedagogi ? Indikator yang relevan termasuk kebijakan dan praktik terkait TIK dalam pendidikan. TIK memiliki potensi yang sangat besar untuk mentransformasikan seluruh aspek di dalam pendidikan di sekolah untuk mencapai tujuan-tujuan pembelajaran.

Sesuai dengan apa yang telah dijelaskan, intrumen utama yang digunakan untuk mengumpulkan informasi yang diperlukan untuk menjawab semua pertanyaan ini adalah dengan menggunakan NCQ, yang mana informasi tersebut akan diberikan kepada SITES NRC. Pengumpulan data menggunakan kuesioner yang diberikan secara online oleh Pusat Pengelolaan Data IEA pada kuartal terakhir di tahun 2016. Kuesioner yang diberikan termasuk kuesioner yang terbuka dan tertutup, pertanyaanya yang mengintegrasikan kedua jenis informasi dan metodelogisnya lebih terkait dengan inikator dan analisis yang tercantum sebelumnya dari laporan teknis SITUS 2006.

Analisis yang dilakukan dibatasi dngan satu level dimana system pendidikan adalah sebagai unit analisis, meskipun terdapat beberapa indikator dasar orientasi pedagogis dan penggunaan TIK di tingat sistem. Pelaporan analisis ini dan temuanya 
dibagi menjadi dua bagian, di dalam dan diantara. Hal pertama berfokus pada distribusi deskriptif dan data kualitatif sedangkan yang kedua terdiri dari analisis eksplanatif atau prediksi yang

\section{Afrika Selatan}

Demokrasi dalam reformasi pendidikan di Afrika Selatan diawali dari kebijakan pemerintahan dan parlemen dengan disusunnya undang-undang persekolahan tahun 1996 yang baru, dan mulai berlaku di awal tahun 1997 yang membawa, menyiapkan tata administrasi persekolahan yang baru, dan memilih dewan sekolah yang baru. Kurikulum pun direformasi berdasarkan kurikulum 2005.

Menurut Karya Ilmu (2006) Sistem persekolahan di Afrika Selatan terdiri atas dua macam bentuk, yaitu

a. Pendidikan melalui persekolah Formal (Education), pendidikan yang pertama ini dilakukan melalui suatu lembaga persekolahan pada umumnya. Ada yang didirikan oleh negara dan ada juga oleh Swasta.

b. Pendidikan melalui Pelatihan (Training), pendidikan ini dilakukan melalui suatu lembaga bukan merupakan suatu lembaga persekolahan tapi melalui suatu kegiatan pelatihan yang dilakukan seperti pendidikan Kejar Paket A di Indonesia.

Kedua bentuk sistem persekolahan tersebut dijalankan dalam tiga tingkatan yakni:
a. Pendidikan dan Pelatihan
Umum/Dasar (General
Education and Training)

pada bagian akhir terdapat integrative berjudul "kesimpulan".

\section{HASIL DAN PEMBAHASAN}

b. Pendidikan dan Pelatihan Lanjutan (Further Education and Training)

c. Pendidikan dan Pelatihan Tinggi (Higher Education and Training).

Pemerintah Asia Afrika telah memberlakukan beberapa hal yang mencerminkan upayanya dalam mengaplikassikan TIK dalam pendidikan, diantaranya yaitu dengan adanya kebijakan layanan TI publik tahun 2001, yang memungkinkan warga negaranya mengakses layanan pemerintahan 24 jam sehari dalam memanfaatkan berbagai alat TIK. Pemerintah Afrika Selatan telah menyetujui kebijakan dan strategi bagi FOSS (Free and Open Sorce software) atau sumber belajar tebuka dan cuma-cuma.

Beberapa inisiatif yang telah dilakukan Afrika Selatan untuk meningkatkan penggunaan TIK dalam sistem pembelajaran terlihat dari sudah diterapkannya TIK dalam sistem managemen dan administrasi sekolah dengan sistem pelacakan dan perekaman informasi unit siswa nasional. Selanjutnya Afrika juga melaksanakan program inisiatif laptop guru atau pendanaan untuk guru membeli laptop. Selain itu terdapat Thutong sebagai portal pendidikan nasional, terdapat pula saluran radio dan saluran televisi pendidikan, dan juga telah berjalan ependidikan di tingkat perguruan tinggi. 
Hanya saja yang masih menjadi massalah adalah perlunya dukungan yang kuat dari pemerintah untuk dapat merealisasikan berbagai program pengimplementasian TIK dalam pendidikan. Pendanaan dan penentuan prioritas investasi TIK sebagai alat pengembangan pun

2. Thailand

Di Thailand, infrastruktur TIK terbatas melarang pengembangan banyak ketrampilan TIK. Pembelajaran dan pengajaran sains dan matematika terhubung dengan pembelajaran berbasis proyek meskipun penggunaan alat TIK, dan di mana internet berlaku. UU Pendidikan Nasional BE $2542 \quad$ (1999) jelas mengidentifikasi ketentuan umum untuk pengembangan Keterampilan abad ke-21, seperti yang didorong oleh teknologi untuk pendidikan. Rencana Pembangunan Ekonomi dan Sosial Nasional ke-9 Thailand (2007-2011), berfokus pada pengembangan kualitas hidup masyarakat Thailand, dalam masyarakat pembelajaran berbasis pengetahuan melalui filsafat "kecukupan" ekonomi ".

Masalah yang terkait dengan penerapan dan penggunaan ICT di pendidikan dibawa ke depan oleh hasil Thailand untuk IEA Ketiga Studi Matematika dan Sains Internasional (TIMSS), OECD Program Penilaian Siswa Internasional (PISA), dan SITES-M1 dan SITUS-M2. Sebagai akibatnya, bahasa ibu, bahasa Inggris, matematika, dan sains kini menjadi area fokus perbaikan. Thailand melihat keterampilan berpikir, proses belajar, dan teknologi yang menjadi hambatan yang serius di Afrika selatan untuk pemanfaatan TIK yang efektif. Membutuhkan backbone dan telekomunikasi yang terjangkau dan aksesibel serta pasokan listrik yang stabil. Kurangnya jumlah professional TI di Afrika Selatan.

digunakan sebagai kendaraan oleh negara yang dapat meningkatkan prestasi siswa di bidang ini khususnya dan keterampilan hidup mereka secara umum.

Pusat Teknologi Pendidikan (CET) di bawah ONFEC bertanggungjawab untuk produksi program televisi dan siaran radio pendidikan, media pendidikan komputer, media untuk peserta didik disabilitas, materi cetak, serta video dan audio untuk menambah bahan belajar pada jenjang pendidikan formal, non formal dan sektor pendidikan sepanjang hayat. CET melaksanaan siaran televisi pendidikan (ETV) dengan waktu tayang 15 jam sehari untuk mendukung pendidikan formal, non formal dan sistem pendidikan informal. Selain itu pula terddapat siaran radio pendidikan 14 jam sehari dan 5 hari dalam seminggu. Selain itu, Thailand juga telah mengaplikasikan pendidikan dan E-Learning atau pembelajaran berbasis teknologim pada sistem pendidikannya.

Tetapi terdapat beberapa hambatan yang menjadi pertimbangan Thailand dalam penerapan TIK dalam sistem pendidikan, diantaranya adalah kurangnya kualifikasi personil ICT, rendahnya insentif untuk personil ICT, kurangnya dukungan pembiayan untuk pemgembangan ICT, tidak 
kondusifnya sikap masyarakat, serangan virus dan tingginya harga peralatan ICT.

3. Slovenia

Sistem pendidikan Slovenia diatur sebagai pelayanan publik di mana baik publik maupun lembaga swasta, serta individu dapat menawarkan hingga 15 tahun. Tingkatannya meliputi pendidikan prasekolah, pendidikan dasar wajib, senior sekunder, dan masuk ke perguruan tinggi yang termasuk kursus pelatihan yang lebih pendek, dan program yang lebih panjang di universitas negeri dan swasta.

Slovenia adalah salah satu negara pasca-sosialis pertama di negara Eropa Tengah yang memperkenalkan dan mengimplementasikan media pendidikan dalam kurikulumnya (Emedus : 2012). Ini berfungsi sebagai model untuk negara-negara bekas Yugoslavia. Menurut laporan itu, Sepuluh tahun Pelatihan Pendidikan Media di Slovenia, oleh Karmen Erjavec dan Zala Volcic, masalah utamanya adalah kurangnya kebijakan pemerintah yang sedang berlangsung pada media pendidikan untuk: membantu mengintegrasikannya secara definitif ke dalam kurikulum, menyediakan fasilitas untuk sekolah dan, mengembangkan program pelatihan guru yang mencakup subjek ini.

Di Slovenia sejak tahun 1996 pendidikan media telah secara resmi menjadi bagian dari kurikulum dari pra-sekolah hingga tingkat universitas (rencana dimulai pada tahun 2000). Pendidikan media di program yang terakreditasi. Kementerian Pendidikan, Sains, dan Olahraga bertanggung jawab atas seluruh sistem pendidikan di Slovenia. Hal ini menciptakan, mengatur dan memonitor lembaga pendidikan.

Pendidikan wajib berlangsung selama sembilan tahun, dari usia 6 sekolah dasar merupakan pilihan mata pelajaran selama tiga tahun terakhir dengan tiga perlakuan yang berbeda setiap tahunnya, yang berfokus pada : radio, televisi, dan internet. Pada tahun pertama mencakup topik yang terkait dengan media cetak. Tahun kedua mengeksplorasi radio dan fitur dan penawaran tahun ketiga dengan televisi dan internet yang diwajibkan.

Slovenia merupakan salah satu negara yang pertama di eropa timur yang mengimplementasikan media pendidikan dalam kurikulum. Dalam kurikulum pendidikan sekolah menengah telah diintegrasikan sebagai pendidikan wajib topik lintas-kurikuler dalam mata pelajaran seperti Bahasa Slovenia, Sosiologi, Psikologi, dan Seni Sejarah (Emedus : 2012). Tujuannya adalah agar siswa belajar menggunakan teknologi baru tetapi juga mengembangkan semangat sehubungan dengan informasi di media.

Asosiasi Guru Media Pendidikan Slovenia menawarkan kursus dan lokakarya dalam pendidikan media untuk guru tertarik pada subjek. Kursus yang mencakup konsep teoritis dan pedagogis praktek untuk 
guru yang ingin mengajar pendidikan media di sekolah dasar.

Terlepas dari hal tersebut, Slovenia memiliki kekurangan dukungan dari otoritas pendidikan untuk mempromosikannya pendidikan di dalam dan untuk media dalam kursus pelatihan guru awal. Tujuannya adalah untuk mengkonversi ini interdisipliner, keterampilan lintaskurikuler menjadi subjek yang tepat dalam pendidikan.

kegiatan pembelajaran bisa dilihat dari kebijakan negara tersebut dan cara masing-masing dalam penerapannya.

Sedangkan, untuk kekurangan dari ketiga negara terseut mempunyai beberapa kesamaan. Seperti ketidakmerataan fasilitas untuk penggunaan TIK, keahlian guru yang kurang maksimal, atau lokasi daerah yang sulit dijangkau yang dapat membuat suatu ketertinggalan.

Dengan adanya kekurangan tersebut dan dipertimbangkan sesuai dengan kawasan tekonologi pendidikan yang meliputi kawasan desain, kawasan pemanfaatan, kawasan pengembangan, kawasan pengelolaan dan kawasan penilaian. Salah satu solusi yang dapat digunakan dalam mengatasi permasalahan kekurangan setiap negara tersebut yaitu dengan menerapkan TV Edu.

TV Edu berisikan mengenai suatu pembahasan suatu bahan ajar dengan narasumber yang memiliki wawasan luas dan ahli dalam bidangnya masingmasing. Penerapan TV Edu ini di sesuaikan dengan kebijakan dan kurikulum setiap Negara masingmasing, dalam TV Edu selain membahas mengenai suatu materi tetapi juga membahas mengenai materi yang

\section{SIMPULAN DAN REKOMENDASI}

Setelah dilakukanya penelitian mengenai pedagogi dan penerapan TIK dalam kegiatan pembelajaran di beberapa bagian negara di dunia terutama di Thailand, Afrika Selatan, dan Slovenia. Dari ketiga negara tersebut memiliki kelebihan serta kekurangannya masing-masing, untuk kelebihan setiap negara dalam menerapkan TIK dalam

menjadi masalah bagi siswa pada saat belajar di sekolah. Teknik pengumpulan suatu masalah pelajaran atau pengajuan suatu materi yang ingin dibahas dapat diajukan melalui email, telepon, atau pun sosial media yang tersedia. Karena TV Edu yang akan diselenggarakan berpacu pada model pembelajaran Learning Start With a Question atau pembelajaran yang dimulai dengan suatu pertanyaan dan setelah dilakukannya voting, maka permasalahan yang paling banyak yang akan dibahas

Program ini dilaksanakan pada hari libur sekolah yaitu sabtu dan minggu. Selain dapat disaksikan di TV, TV Edu ini pun menyediakan dalam bentuk video yang diunggah dalah media sosial sehingga siswa dapat sewaktuwaktu membukanya. Sebagai bahan evaluasi kegiatan TV Edu, setiap akhir acara diajukan sebuah pertanyaan berupa kuis berhadiah yang pertanyaan tersebut bisa dijawab melalui telepon secara langsung ataupun dalam media sosial. Selain itu, setiap tengah semester ataupun akhir semester diadakan suatu cerdas cermat yang diwakili oleh siswa setiap sekolahnya. Dengan melaksanakan program tersebut, diyakini dapat membantu siswa dalam belajar dan juga membantu pemerataan dan mengatasi masalah penerapan TIK 
Kegunaan Televisi Dalam Membantu Memecahkan Masalah Belajar dan Pembelajaran

dalam pembelajaran di masing-masing negara.

\section{DAFTAR PUSTAKA}

Darmawan,(2017). Pendidikan Teknologi Informasi dan Komunikasi. Bandung: Rosda.

Guru Online. (2015). TIK dalam Pendidikan (Sebuah Studi Kasus di Afrika Selatan). [online],tersedia di: https://www.slideshare.net. Diakses pada: 25 Oktober 2018.

di:https://www.scribd.com. Diakses pada: 25 Oktober 2018
Ilmu, Karya. (2016). Pendidikan di Afrika Selatan; Perbandingan Pendidikan. [online], diakses pada:

https://karyailmu99.com. Diakses pada: 23 Oktober 2018

Kustiana, Yudi. (2012). Pengelolaan Belajar Berbasis TIK. [online], diakses pada: https://yudikustiana.com. Diakses pada: 24 Oktober 2018.

Sewu, Lawang. (2013). Teknologi Informasi dan Komunikassi di Tahiland. [online]. Tersedia 